\title{
STUDI KEMAMPUAN KOMPONEN LABA-RUGI SEBAGAI PREDIKTOR KOMPONEN ARUS KAS MASA DEPAN
}

\author{
Syamsul Rijal \\ Institut Teknologi dan Bisnis Kalla \\ e-mail: syamsul.rijal@gmail.com
}

\begin{abstract}
Abstrak
Penelitian ini bertujuan untuk menganalisis relevansi komponen laba rugi sebagai prediktor terhadap masing-masing komponen arus kas. Analisis data menggunakan metode statistik berupa regresi linear berganda, dengan tipe data yaitu pooled data. Data terdiri atas 40 cross-sectional observasi dan 3 time-series observasi yang terdiri atas perubahan arus kas operasi $\left(\Delta \mathrm{AKO}_{\mathrm{t}}\right)$, perubahan arus kas investasi $\left(\Delta \mathrm{AKI}_{\mathrm{t}}\right)$, perubahan arus kas pendanaan $\left(\Delta \mathrm{AKD}_{\mathrm{t}}\right)$ dan perubahan laba bruto $\left(\Delta \mathrm{LB}_{\mathrm{t}-1}\right)$, perubahan laba operasi $\left(\Delta \mathrm{LO}_{\mathrm{t}-1}\right)$, perubahan laba bersih $\left(\Delta \mathrm{LN}_{\mathrm{t}-1}\right)$, sehingga terdapat 720 pooled observasi. Dengan menggunakan model pooled data, maka variabel dependent terdiri atas $\Delta \mathrm{AKO}_{\mathrm{t}}$ atau $\triangle \mathrm{AKI}_{\mathrm{t}}$ atau $\triangle \mathrm{AKD}_{\mathrm{t}}$ perusahaan sejak tahun (2017-2016) sampai (2019-2018). Variabel independent adalah $\Delta \mathrm{LB}_{\mathrm{t}-1}, \Delta \mathrm{LO}_{\mathrm{t}-1}$ dan $\Delta \mathrm{LN}_{\mathrm{t}-1}$ satu tahun sebelumnya dimulai sejak tahun (2016-2015) sampai (2018-2017).

Dari hasil uji statistik disimpulkan bahwa: pertama, komponen laba-rugi secara signifikan dapat menjadi prediktor komponen arus kas dari kegiatan operasi; kedua, komponen laba-rugi tidak signifikan untuk menjadi prediktor komponen arus kas dari kegiatan investasi dan ketiga, komponen laba-rugi secara signifikan dapat menjadi prediktor komponen arus kas dari kegiatan pendanaan.

Kata kunci: Komponen laba-rugi, komponen arus kas.
\end{abstract}

\section{ABSTRACT}

This study aims was to test the relationship of the ability of earnings component in predicting each cash flow component. This research using statistical method linear regression by using pooled data, which is consist of 40 cross-sectional observations and 3 time series observations. Dependent variable is cash flow operations change $\left(\triangle C F O_{t}\right)$ or cash flow from investing activities changes $\left(\Delta C F I_{t}\right)$ or cash flow from financing activities changes $\left(\left(\Delta C F F_{t}\right)\right.$ from the period (2017-2016) to (2019-2018). Independent variables are gross profit changes $\left(\Delta G P_{t-1}\right)$, operations profit changes $\left(\Delta O P_{t-1}\right)$ and net profit changes $\left(\Delta N I_{t-1}\right)$ from $(2016-2015)$ to (2018-2017).

The conclusion from statistical analysis shows that: first, earnings component are significant in predicting cash flow from operations one year ahead. Second, earnings component were not significant in predicting cash flow from investment activities one year ahead. Lastly, earnings component are significant in predicting cash flow from financing activities one year ahead.

Key words: Earnings component, cash flow component

\section{PENDAHULUAN}

Laporan keuangan menggambarkan kinerja entitas dalam suatu periode tertentu berupa informasi laba, yang memiliki manfaat untuk membantu mengestimasi kemampuan laba yang akan datang, dan menaksir risiko dalam investasi. Informasi lainnya, berupa laporan arus kas yang dapat digunakan untuk mengevaluasi kemampuan perusahaan menghasilkan dan menggunakan kas. Dengan menggunakan kedua informasi laporan keuangan tersebut, pihak 
manajemen dan investor lebih komprehensif dalam memprediksi kondisi keuangan dimasa depan dengan menggunakan data kinerja keuangan saat ini.

Dalam menilai suatu investasi, laba merupakan komponen penting karena laba mencerminkan keuntungan yang dihasilkan oleh perusahaan dan mencerminkan return yang dapat diperoleh pemegang saham. Walaupun laba tersebut tidak seluruhnya diberikan kepada pemegang saham, akan tetapi laba yang ditahan tersebut diharapkan dapat menghasilkan keuntungan yang lebih besar yang pada akhirnya akan memberikan keuntungan bagi investor. Selain itu laba juga dipergunakan sebagai dasar dalam analisis fundamental untuk memprediksi nilai intrinsik satu perusahaan.

Estimasi arus kas merupakan faktor penting dalam melakukan evaluasi, bahkan masalah dalam penaksiran arus kas bukan hanya menyangkut keakurasian taksiran, tetapi juga memperhatikan arus kas yang relevan. Evaluasi atas keakurasian ini penting, karena untuk mewaspadai adanya kesalahan penaksiran. Evaluasi ini juga dilakukan terhadap arus kas yang relevan, menurut (Husnan, 1994) hal-hal yang perlu diperhatikan adalah, arus kas ditaksir atas dasar laba setelah pajak dan selisih (inkremental). Serta, arus kas dari kegiatan investasi dan pendanaan.

Penyajian laporan arus kas dapat menjadi informasi dasar dalam penilaian harga pasar sekuritas. Jumlah arus kas dari kegiatan operasi merupakan indikator untuk menentukan apakah arus kas yang dihasilkan dari kegiatan operasi perusahaan cukup untuk melunasi pinjaman, memelihara kemampuan operasi perusahaan, membayar dividen dan melakukan investasi baru tanpa mengandalkan pada sumber pendanaan dari luar.

Prediksi arus kas dan komponen arus kas, dapat menjadi dasar bagi investor dalam membuat perencanaan untuk keputusan dimasa yang akan datang. Untuk dapat memperoleh validasi dan keefisienan dalam prediksi, maka perlu dicari variabel prediktor - dalam hal ini komponen laba-rugi - yang dapat dipergunakan dalam membuat prediksi yang akan datang. Seandainya dapat, maka seberapa besar varibel tersebut dapat dipergunakan untuk keperluan prediksi.

Investor dan kreditur dihadapkan pada situasi ketidakpastian resiko dimasa depan. Gambaran tentang kualitas kinerja perusahaan dijelaskan dalam publikasi laporan keuangan yang merupakan salah satu informasi penting yang dikeluarkan perusahaan kepada para investor di pasar modal, dengan fokus utama laporan keuangan tersebut adalah pada laporan laba rugi (Susilowati, 2011). Akan tetapi, ternyata dalam perkembangannya, informasi laba rugi ternyata mempunyai beberapa kelemahan, sehingga kemudian laporan arus kas banyak digunakan sebagai dasar pengambilan keputusan (Sri Mar'ati, 2009). Berdasarkan pada kemampuan informasi akuntansi untuk memenuhi tujuan laporan keuangan dalam proses pengambilan keputusan (Yuwana dan Jogi, 2014), investor dapat memperoleh informasi akuntansi dari laporan keuangan yang tersedia. Laporan keuangan merupakan sarana acuan bagi kreditur dan investor dalam pengambilan keputusan.

Prestasi kinerja perusahaan dapat diketahui dari informasi laporan laba rugi selama periode tertentu. Informasi yang terkandung dalam laporan laba rugi dapat dijadikan dasar untuk menilai ketidakpastian arus kas, karena dapat menjadi dasar untuk memprediksi kinerja perusahaan dimasa depan. Laba bersih secara parsial memiliki kemampuan untuk memprediksi arus kas operasi masa depan. Demikian pula dengan arus kas operasi secara parsial juga berpengaruh signifikan dalam menjadi prediktor bagi arus kas operasi masa depan. (Yuwana dan Jogi, 2014). Laporan arus kas mengandung informasi tentang aliran kas masuk dan aliran kas keluar dari perusahaan selama periode tertentu. Menurut Pernyataan Standar Akuntansi Keuangan Nomor 2 tahun 2015 informasi yang disajikan dalam laporan arus kas jika digunakan dalam kaitannya dengan laporan keuangan lain dapat berguna untuk menilai kemampuan 
perusahaan dalam menghasilkan kas dan setara kas, dan memungkinkan para pengguna informasi untuk mengembangkan model, untuk menilai, dan membandingkan nilai sekarang dari arus kas masa depan (future cash flow) dari berbagai perusahaan (Mufidah, 2017). Secara parsial laba dan arus kas memiliki pengaruh positif terhadap arus kas masa depan pada perusahaan (Maulida dkk, 2018).

Pada dasarnya laporan laba-rugi melaporkan jumlah aliran masuk aktiva - kas atau piutang - yang merupakan hasil penjualan barang atau jasa; jumlah tersebut adalah pendapatan atau revenue atau sales revenue yang merupakan aliran masuk (kenaikan) aktiva suatu perusahaan atau penurunan utangnya (atau kombinasi keduanya) dalam satu periode tertentu dari penyerahan barang dagangan, hasil produksi, penyerahan jasa, atau aktivitas lain yang merupakan usaha pokok atau central operations. Selain itu, laporan laba-rugi melaporkan aliran keluar (consumption) sumber daya ekonomik yang berkaitan dengan usaha untuk memperoleh pendapatan. Laba rugi terdiri atas beberapa komponen, antara lain; laba bruto, laba operasi atau laba usaha, dan laba bersih.

Laporan arus kas menyediakan informasi yang relevan tentang penerimaan dan pengeluaran kas suatu perusahaan dalam satu periode. Apabila informasi arus kas dipergunakan bersama dengan informasi yang berhubungan dan yang ada dalam laporan keuangan lainnya, maka akan bermanfaat bagi investor, kreditor dan pihak-pihak lainnya dalam berbagai evaluasi terhadap perusahaan, terutama yang terkait dengan penggunaan kas. Laporan arus kas dapat digunakan oleh manajemen perusahaan untuk mengevaluasi kegiatan operasi yang telah lalu dan dalam membuat perencanaan investasi dan kegiatan pendanaan dimasa depan. Laporan arus kas menunjukkan:

a. Arus kas dari kegiatan operasi

b. Arus kas dari kegiatan investasi

c. Arus kas dari kegiatan pendanaan

Penyajian laporan arus kas secara rinci sangat penting karena masing-masing komponen tersebut mempunyai pengaruh yang berbeda-beda dalam pembuatan keputusan oleh pihak-pihak yang berkepentingan dengan laporan arus kas suatu perusahaan.

Informasi arus kas dapat dipergunakan untuk mengevaluasi perubahan struktur keuangan seperti likuiditas dan solvabilitas serta hubungannya dengan profitabilitas. Selain itu, informasi arus kas dapat dipergunakan untuk memprediksi dividen, jumlah arus kas dari kegiatan operasi khususnya merupakan indikator untuk menentukan apakah arus kas yang dihasilkan cukup untuk memelihara kemampuan operasi, untuk melunasi pinjaman, serta untuk melakukan investasi baru tanpa mengandalkan pada sumber pendanaan dari luar. Laba dan arus kas merupakan keuntungan investasi modal (benefit of equity investment), merupakan informasi penting bagi para investor untuk mengetahui perkembangannya.

Penelitian (Sugiri, 2003) terhadap kemampuan laba rincian untuk memprediksi arus kas, dengan tujuan penelitian adalah untuk mencari bukti empirik bahwa laba rincian memiliki predictive content, laba rincian mengungguli laba agregat dalam kemampuan prediktifnya, dan untuk mengetahui apakah kualitas laba memperkuat kemampuan laba rincian dalam memprediksi arus kas. Hasil penelitian menunjukkan bahwa: laba yang dirinci ke dalam laba operasi dan non-operasi memiliki predictive content, laba operasi memiliki predictive content, tetapi laba non-operasi tidak, laba operasi lebih kuat daripada laba non-operasi dalam kemampuannya untuk memprediksi arus kas, laba yang dirinci ke dalam dua komponen (laba operasi dan laba non-operasi) adalah lebih kuat daripada laba agregat dalam memprediksi arus kas. 
Secara umum, informasi arus kas dapat digunakan mengevaluasi kemampuan perusahaan untuk memenuhi kewajibannya, melunasi deviden, meningkatkan kapasitas, dan mendapatkan dana. Informasi arus kas juga membantu dalam mengevaluasi kualitas laba dan ketergantungan margin atas perkiraan serta anggapan mengenai arus kas masa yang akan datang (Subramanyam, 2010). Dalam memprediksikan kondisi suatu perusahaan di masa yang akan datang para pelaku ekonomi dan bisnis memerlukan data laporan keuangan periode sebelumnya untuk membantu dalam melalukikan prediksi tersebut. Salah satu laporan keuangan yang bisa digunakan untuk alat mempertimbangkan dalam membuat keputusan ekonomi adalah laporan arus kas. Hal ini menunjukkan bahwa penilaian performa suatu perusahaan sebaiknya tidak hanya pada laporan laba rugi dan neraca (Prayoga 2012). Selanjutnya, Jing et. al, (2010) dalam Nany (2013) menjelaskan bahwa kemampuan prediksi mempengaruhi kualitas suatu informasi. Informasi yang relevan harus memiliki predictive value.

Kinerja keuangan perusahaan merupakan hal yang penting bagi investor (Abdullah, 2019), yang dapat dilihat dari informasi laporan laba rugi dan dari laporan arus kas yang mampu meramalkan kas masuk dan keluar (Adnyani, 2015). Sehingga penting untuk mengamati suatu sinyal (laporan keuangan) sebelum melakukan suatu prediksi. Hal tersebut bermanfaat untuk mengetahui keadaan perusahaan sesungguhnya pada saat ini dan membandingkannya dengan keadaan sebelumnya.

Beberapa studi terdahulu telah menguji kandungan informasi dari laporan laba rugi dan laporan arus kas, namun yang menjadi pertanyaan bagi peneliti saat ini adalah; apakah komponen laba yang terdiri atas laba bruto, laba operasi dan laba bersih memiliki kemampuan menjadi prediktor apabila dipergunakan untuk memprediksi masing-masing komponen arus kas dimasa depan yang terdiri atas arus kas dari kegiatan operasi atau arus kas dari kegiatan investasi atau arus kas dari kegiatan pendanaan. Berdasarkan hal tersebut, dibuat kerangka pikir sebagai berikut:

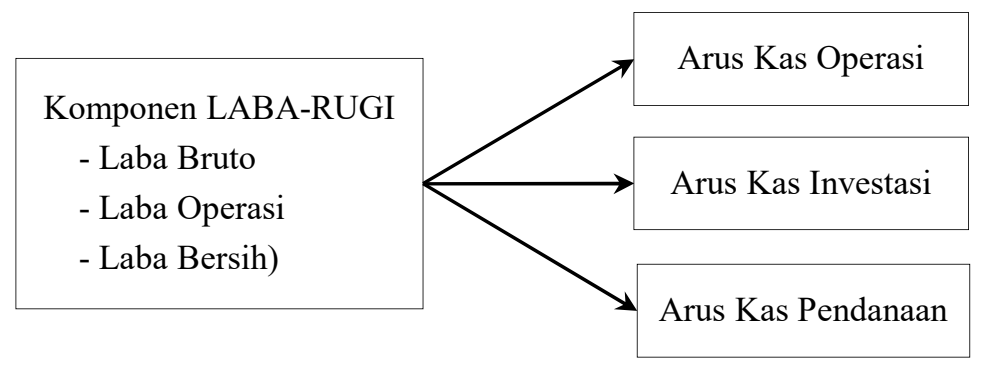

Dari kerangka pikir diatas, hipotesis yang dikembangkan adalah:

1. Komponen laba-rugi dapat dipergunakan sebagai prediktor arus kas dari kegiatan operasi;

2. Komponen laba-rugi dapat dipergunakan sebagai prediktor arus kas dari kegiatan investasi;

3. komponen laba-rugi dapat dipergunakan sebagai prediktor arus kas dari kegiatan pendanaan.

\section{METODE PENELITIAN}

Penelitian ini menggunakan pendekatan kuantitatif deskriptif, dengan menggunakan metode statistik regresi linear berganda dalam analisis datanya. Tipe data yaitu pooled data yang terdiri atas 40 cross-sectional observasi dan 3 time-series observasi yaitu, perubahan arus kas operasi, perubahan arus kas investasi, perubahan arus kas pendanaan dan perubahan laba bruto, perubahan laba operasi, perubahan laba bersih, sehingga terdapat 720 pooled observasi. 
Dengan menggunakan model pooled data, maka variabel dependent terdiri atas perubahan arus kas operasi ( $\Delta$ arus kas operasi $\left.i_{t}\right)$ atau perubahan arus kas dari kegiatan investasi ( $\Delta$ arus kas investasi $i_{t}$ ) atau perubahan arus kas dari kegiatan pendanaan ( $\Delta$ arus kas pendanaan ${ }_{t}$ ) perusahaan. Variabel independent terdiri atas perubahan laba bruto $\left(\Delta\right.$ laba bruto $\left._{t-1}\right)$, perubahan laba operasi $\left(\Delta\right.$ laba operasi $\left.i_{t-1}\right)$ dan perubahan laba bersih ( $\Delta$ laba bersih $\left.{ }_{t-1}\right)$ satu tahun sebelumnya. Sehingga pada masing-masing variabel terdapat 120 data.

Persamaan regresi sebagai estimasi peramalan dipergunakan untuk menentukan koefisien variabel-variabel dalam persamaan regresi dari masing-masing komposisi pemisahaan laba (model peramalan). Adapun langkah-langkahnya adalah data perubahan komponen laba dipergunakan untuk membentuk persamaan regresi sebagai prediktor, sedangkan data perubahan masing-masing komponen arus kas dipergunakan untuk data prediksi. Untuk mendapatkan perubahan komponen laba-rugi periode $\mathrm{t}$, maka masing-masing komponen laba-rugi pada tahun $\mathrm{t}$ dikurangi dengan masing-masing komponen laba-rugi dari tahun $\mathrm{t}-1$. Demikian pula untuk mendapatkan perubahan komponen arus kas periode $t$, maka masing-masing komponen arus kas pada tahun $\mathrm{t}$ dikurangi dengan masing-masing komponen arus kas pada tahun t-1 ( $\Delta Y_{i t}=Y_{i t}-$ $\left.Y_{i t-l}\right)$. Penggunaan angka perubahan komponen laba-rugi dan perubahan komponen arus kas, akan mengurangi efek firm size (Machfoedz, 1994). Prediksi dipergunakan dengan time lag satu tahun untuk mengetahui apakah perubahan komponen laba-rugi periode satu tahun sebelumnya dapat menjadi prediktor masing-masing komponen arus kas satu tahun kedepan.

Sesuai dengan model peramalan yang dipergunakan, bentuk persamaan regresi yang akan diperoleh adalah sebagai berikut:

$$
\mathrm{A}_{\mathrm{t}}=\alpha+\beta_{1} \Delta \mathrm{LB}_{\mathrm{t}-1}+\beta_{2} \Delta \mathrm{LO}_{\mathrm{t}-1}+\beta_{3} \Delta \mathrm{LN}_{\mathrm{t}-1}+\varepsilon_{\mathrm{t}}
$$

Dalam hal ini,

A adalah perubahan arus Kas (arus kas dari kegiatan operasi).

$\triangle \mathrm{LB} \quad$ adalah perubahan laba bruto (periode $\mathrm{t}-\mathrm{t}-1$ );

$\Delta \mathrm{LO} \quad$ adalah perubahan laba operasi (periode $\mathrm{t}-\mathrm{t}-1$ );

$\triangle \mathrm{LN}$ adalah perubahan laba bersih (periode $\mathrm{t}-\mathrm{t}-1$ );

$\alpha \quad$ adalah intersep persamaan regresi;

$\beta \quad$ adalah koefisien regresi komponen laba;

$\varepsilon \quad$ adalah error term;

$\mathrm{t}$ adalah periode $\mathrm{t}$ (periode dalam tahun).

Kesimpulan atas tes hipotesis dilakukan dengan mengamati nilai koefisien regresi $(\beta)$, dengan mempertimbangkan hasil uji signifikan yaitu uji-F dan uji-t, serta nilai koefisien determinasi $\left(\mathrm{R}^{2}\right)$. Penelitian ini juga mengasumsikan adanya hubungan yang konstan antara data akuntansi dalam periode pengamatan dan perubahan metode atau lingkungan ekonomi dari sampel selama periode pengamatan.

\section{HASIL DAN PEMBAHASAN}

Pengujian untuk mengetahui kemampuan komponen laba-rugi ( $\Delta$ laba bruto, $\Delta$ laba operasi, $\Delta$ laba bersih) dalam memprediksi komponen arus kas ( $\Delta$ arus kas dari kegiatan operasi atau $\Delta$ arus kas dari kegiatan investasi atau $\Delta$ arus kas dari kegiatan pendanaan) yang akan datang dipergunakan model regresi linear.

\section{A. KOMPONEN LABA-RUGI SEBAGAI PREDIKTOR ARUS KAS DARI KEGIATAN OPERASI}


Pengujian kemampuan komponen laba-rugi satu tahun sebelumnya ( $\Delta$ laba brutot-1, $\Delta$ laba operasi $i_{t-1}, \Delta$ laba bersih ${ }_{t-1}$ ) sebagai prediktor arus kas dari kegiatan operasi ( $\Delta$ arus kas operasi $i_{t}$ ), menggunakan model regresi linier sebagai berikut:

$$
\Delta \mathrm{AKO}_{\mathrm{t}}=\alpha+\beta_{1} \Delta \mathrm{LB}_{\mathrm{t}-1}+\beta_{2} \Delta \mathrm{LO}_{\mathrm{t}-1}+\beta_{3} \Delta \mathrm{LN}_{\mathrm{t}-1}+\varepsilon_{\mathrm{t}}
$$
berikut ini:

Hasil pengujian dengan menggunakan model regresi di atas disajikan pada tabel 1

Tabel 1. Prediksi Komponen Laba-rugi terhadap Arus Kas Dari Kegiatan Operasi

\begin{tabular}{|c|c|c|c|c|}
\hline $\begin{array}{ll}R \text {-Square } & 0,456 \\
\text { Adjusted R Square } & 0,442\end{array}$ & \multicolumn{2}{|c|}{$\begin{array}{r}32,456 \\
0,000\end{array}$} & \multicolumn{2}{|c|}{ Durbin-Watson 2,115} \\
\hline Variabel & Coefficient (B) & $\mathbf{t}$ & Sig. & VIF \\
\hline $\operatorname{Dlt}_{\mathrm{LB}}^{(\mathrm{t}-1-\mathrm{t}-2)}$ & 0,487 & 3,955 & 0,000 & 1,926 \\
\hline Dlt LO $(t-1-t-2)$ & $-1,024$ & $-5,235$ & 0,000 & 2,729 \\
\hline Dlt LB $(t-1-t-2)$ & $-0,145$ & $-2,310$ & 0,023 & 1,951 \\
\hline
\end{tabular}

Pada tabel 1. Dapat dilihat bahwa nilai $\mathrm{R}^{2}$ model (1) sebesar 0,456 . Hal ini berarti bahwa seluruh variabel komponen laba-rugi satu tahun yang lalu ( $\Delta$ laba bruto $t_{-1}, \Delta$ laba operasi $i_{-}$ 1, $\Delta$ laba bersih $\mathrm{t}_{\mathrm{t}-1}$ ) mempunyai kemampuan memprediksi arus kas dari kegiatan operasi sebesar $45,6 \%$. sedangkan sisanya $54,4 \%$ dijelaskan oleh variabel lain di luar model. Nilai F-test adalah 32,465 dengan tingkat signifikan 0,000 jauh dibawah 0,05 , sehingga model regresi di atas secara signifikan dapat dipergunakan untuk memprediksi arus kas dari kegiatan operasi.

Hasil uji statistik t menunjukkan nilai signifikansi, nampak bahwa perubahan laba bruto, perubahan laba operasi dan perubahan laba bersih satu tahun yang lalu mempunyai angka signifikan dibawah 0,05, masing-masing yaitu 0,000; 0,000; dan 0,023. Oleh karena itu perubahan masing-masing komponen laba-rugi satu tahun yang lalu mempengaruhi perubahan arus kas dari kegiatan operasi tahun ini. Dengan demikian maka kemungkinan menerima hipotesis adalah 95\%, berarti hasil ini sesuai dengan hipotesis yang pertama (H1) yaitu, bahwa komponen laba-rugi dapat dipergunakan sebagai prediktor arus kas dari kegiatan operasi

Berdasarkan hasil pengujian dengan menggunakan model (1) di atas, dapat diambil kesimpulan bahwa ketiga komponen laba-rugi dari periode satu tahun yang lalu secara signifikan mempunyai kemampuan untuk memprediksi arus kas dari kegiatan operasi. Hasil yang diperoleh ini sesuai dengan penelitian (Sugiri, 2003) bahwa laba yang dirinci ke dalam laba operasi dan laba non-operasi berguna untuk memprediksi arus kas periode mendatang, serta Werdiningsih dan (Jogiyanto, 2001) bahwa klasifikasi komponen laba yang semakin rinci dapat meningkatkan kemampuan prediksi laba, demikian pula hasil penelitian (Sutedja, 2018) yang menyimpulkan bahwa komponel Laba Rugi memiliki kemampuan prediksi terhadap arus kas dari kegiatan operasi dimasa depan.

\section{B. KOMPONEN LABA-RUGI SEBAGAI PREDIKTOR ARUS KAS DARI KEGIATAN INVESTASI}

Hasil keuntungan atau laba yang diperoleh perusahaan tidak hanya digunakan untuk pendanaan kegiatan operasional, selain itu digunakan juga untuk kegiatan investasi yang bertujuan untuk menghasilkan pendapatan dan arus kas dimasa depan. Oleh karena itu komponen laba-rugi akan berpengaruh pada arus kas dari kegiatan investasi perusahaan.

Untuk Pengujian kemampuan komponen laba-rugi satu tahun sebelumnya ( $\Delta$ laba brutot1, Slaba operasi $\mathrm{i}_{\mathrm{t}-1}, \Delta$ laba bersih $\mathrm{t}_{\mathrm{t}-1}$ ) sebagai prediktor arus kas dari kegiatan investasi, akan menggunakan persamaan regresi sebagai berikut: 


\section{AkMen}

Volume 17 Nomor 3 September 2020

Hal.348 - 357

e-ISSN : 2621-4377 \& p-ISSN : 1829-8524

Hbmepage: https//e-jurnal.stienobel-indonesia.acid/index.php/akmen berikut ini:

$$
\Delta \mathrm{AKI}_{\mathrm{t}}=\alpha+\beta 1 \Delta \mathrm{LB}_{\mathrm{t}-1}+\beta 2 \Delta \mathrm{LO}_{\mathrm{t}-1}+\beta 3 \Delta \mathrm{LN}_{\mathrm{t}-1}+\varepsilon_{\mathrm{t}}
$$

Hasil pengujian dengan menggunakan model regresi di atas disajikan pada tabel 2

Tabel 2. Prediksi Komponen Laba-rugi terhadap Arus Kas Dari Kegiatan Investasi

\begin{tabular}{|c|c|c|c|c|}
\hline $\begin{array}{ll}R \text {-Square } & 0,091 \\
\text { Adjusted R Square } & 0,067\end{array}$ & \multicolumn{2}{|l|}{$\begin{array}{l}\text { F-Value } \\
P \text {-Value }\end{array}$} & \multicolumn{2}{|c|}{ Durbin-Watson 1,461} \\
\hline Variabel & Coefficient (B) & $\mathbf{t}$ & Sig. & VIF \\
\hline Dlt LB $(t-1-t-2)$ & 0,177 & 1,468 & 0,145 & 1,926 \\
\hline Dlt LO $(t-1-t-2)$ & 0,138 & 0,723 & 0,471 & 2,729 \\
\hline Dlt LB $(t-1-t-2)$ & 0,062 & 1,008 & 0,315 & 1,951 \\
\hline
\end{tabular}

Tabel 2. menunjukkan hasil estimasi variabel komponen laba-rugi sebagai variabel bebas (independent) dengan arus kas dari kegiatan investasi sebagai variabel tergantung (dependent).

Dari perhitungan nilai $\mathrm{R}^{2}$ model (2) diperoleh hasil sebesar 0,091. Hal ini berarti bahwa hanya sebesar 9,1\% perubahan arus kas dari kegiatan investasi perusahaan dapat dijelaskan oleh variabel komponen laba-rugi (perubahan laba bruto, perubahan laba operasi, dan perubahan laba bersih), sedangkan sisanya sebesar 90,9\% dijelaskan oleh variabel lain di luar model. Nilai Ftest adalah 3,861 lebih kecil dari 4, maka dapat dikatakan bahwa seluruh variabel independen tidak signifikan untuk memprediksi variabel dependen. Sehingga model (2) tidak dapat dipergunakan untuk memprediksi arus kas dari kegiatan investasi satu tahun ke depan.

Hasil Uji statistik t dari kolom nilai signifikansi, nampak bahwa perubahan laba bruto, perubahan laba operasi dan perubahan laba bersih satu tahun yang lalu mempunyai angka di atas 0,05 , yaitu masing-masing $1,468,0,723$, dan 1,008. Sehingga dapat disimpulkan bahwa masingmasing variabel komponen laba-rugi satu tahun yang lalu secara individual tidak mempunyai pengaruh yang signifikan terhadap arus kas dari kegiatan investasi tahun ini.

Dari hasil pengujian menggunakan model (2) di atas dapat diambil kesimpulan bahwa, nilai $\mathrm{R}^{2}$ dan nilai F-test serta nilai t-test menunjukkan nilai yang tidak signifikan. Hal ini berarti bahwa hipotesis kedua (H2) tidak didukung oleh data atau tidak sesuai dengan harapan peneliti, sehingga dapat dikatakan bahwa dalam pengujian ini kemungkinan menolak hipotesis alternatif lebih besar dari 5\%, dan ketiga komponen laba yang menjadi variabel independen secara individual tidak mempunyai kandungan informasi terhadap arus kas investasi perusahaan sampel.

Hasil pengujian tersebut menunjukkan bahwa kebijakan investasi oleh perusahaanperusahaan sampel sangat sulit diprediksi dengan menggunakan informasi laporan laba-rugi satu tahun yang lalu. Seperti dijelaskan oleh Wild (2001) dalam Yustitia (2002) bahwa periode peramalan laba yang terlalu pendek terkadang tidak bisa diandalkan, karena berdasarkan sifat alamiah pada investasi dan aktivitas pembiayaan yang diterapkan suatu perusahaan membutuhkan waktu untuk memperoleh laba dan penghasilan. Selain itu, kemungkinan karena kegiatan investasi akan dilakukan apabila tersedia dana dalam bentuk kas. Kenyataan tersebut dapat juga terjadi karena keuntungan yang diperoleh tahun sebelumnya oleh perusahaan sampel tidak dipergunakan untuk investasi, tetapi dipergunakan untuk memperbaiki struktur pendanaannya.

\section{KOMPONEN LABA-RUGI SEBAGAI PREDIKTOR ARUS KAS DARI KEGIATAN PENDANAAN}


Model regresi linear yang dipergunakan untuk pengujian kemampuan komponen labarugi ( $\Delta$ laba bruto t-1 $_{1}, \Delta$ laba operasi $\mathrm{t}_{\mathrm{t}-1}, \Delta \mathrm{laba}_{\mathrm{bersih}} \mathrm{t}_{\mathrm{t}-1}$ ) sebagai prediktor arus kas dari kegiatan operasi adalah sebagai berikut:

$$
\Delta \mathrm{AKD}_{\mathrm{t}}=\alpha+\beta_{1} \Delta \mathrm{LB}_{\mathrm{t}-1}+\beta_{2} \Delta \mathrm{LO}_{\mathrm{t}-1}+\beta_{3} \Delta \mathrm{LN}_{\mathrm{t}-1}+\varepsilon_{\mathrm{t}}
$$
berikut ini:

Hasil pengujian dengan menggunakan model regresi di atas disajikan pada tabel 3

Tabel 3. Prediksi Komponen Laba-rugi terhadap Arus Kas Dari Kegiatan Pendanaan

\begin{tabular}{|c|c|c|c|c|}
\hline $\begin{array}{ll}R \text {-Square } & 0,475 \\
\text { Adjusted R Square } & 0,461\end{array}$ & \multicolumn{2}{|l|}{$\begin{array}{l}\text { F-Value } \\
P \text {-Value }\end{array}$} & \multicolumn{2}{|c|}{ Durbin-Watson 1,617} \\
\hline Variabel & Coefficient (B) & $\mathbf{t}$ & Sig. & VIF \\
\hline Dlt LB $(t-1-t-2)$ & $-0,560$ & $-4,450$ & 0,000 & 1,926 \\
\hline $\operatorname{Dlt} \mathrm{LO}_{(\mathrm{t}-1-\mathrm{t}-2)}$ & 0,862 & 4,315 & 0,000 & 2,729 \\
\hline Dlt LB $(t-1-t-2)$ & 0,217 & 3,371 & 0,001 & 1,951 \\
\hline
\end{tabular}

Pada Tabel 3. Dapat dilihat hasil estimasi variabel perubahan komponen laba-rugi sebagai variabel bebas (independent) dengan perubahan arus kas dari kegiatan pendanaan sebagai variabel tergantung (dependent).

Dari hasil pengujian model (3) di atas diperoleh nilai $\mathrm{R}^{2}$ sebesar 0,475 , Hal ini berarti bahwa seluruh variabel komponen laba-rugi satu tahun yang lalu ( $\Delta$ laba brutot-1, $\Delta$ laba operasit1, $\Delta$ laba bersiht-1) mampu memprediksi arus kas dari kegiatan pendanaan sebesar $47,5 \%$. sedangkan sisanya 52,5\% dijelaskan oleh variabel lain di luar model. Nilai F-test adalah 34,918 dengan tingkat signifikan 0,000 jauh dibawah 0,05. Dengan demikian dapat dikatakan bahwa variabel komponen laba-rugi satu tahun yang lalu dapat dipergunakan sebagai prediktor untuk memprediksi perubahan arus kas dari kegiatan pendanaan tahun ini.

Dari kolom signifikansi (Uji t), terlihat bahwa perubahan laba bruto, perubahan laba operasi, dan perubahan laba bersih satu tahun yang lalu mempunyai angka dibawah 0,05 , yaitu masing-masing; 0,000, 0,000, dan 0,001. Oleh karena itu perubahan masing-masing komponen laba-rugi satu tahun yang lalu secara individual mempunyai pengaruh signifikan terhadap arus kas dari kegiatan pendanaan tahun ini. Sehingga dapat diambil kesimpulan bahwa komponen laba-rugi dapat dipergunakan sebagai prediktor arus kas dari kegiatan pendanaan, oleh karena komponen laba-rugi satu tahun yang lalu secara signifikan mempunyai kemampuan untuk memprediksi arus kas dari kegiatan pendanaan satu tahun ke depan, atau.

Hubungan antara variabel perubahan komponen laba-rugi sebagai variabel bebas (independent) dengan perubahan arus kas dari kegiatan pendanaan sebagai variabel tergantung (dependent) dapat dilihat pada nilai koefisien regresi dari masing-masing variabel bebas (independent). Koefisien regresi $(\beta) \Delta \mathrm{LB}_{\mathrm{t}-1}$ adalah negatif sebesar $-0,560$, berarti perubahan laba bruto satu tahun sebelumnya berpengaruh negatif terhadap perubahan arus kas dari kegiatan pendanaan sebesar $56,0 \%$. Sedangkan koefisien regresi $(\beta) \Delta \mathrm{LO}_{\mathrm{t}-1}$ adalah positif sebesar 0,862 , berarti perubahan laba operasi satu tahun sebelumnya berpengaruh positif terhadap perubahan arus kas dari kegiatan pendanaan sebesar $86,2 \%$, demikian juga koefisien regresi $(\beta) \Delta \mathrm{LN}_{\mathrm{t}-1}$ adalah positif sebesar 0,217 , berarti perubahan laba bersih satu tahun sebelumnya berpengaruh positif terhadap perubahan arus kas dari kegiatan pendanaan sebesar 21,7\%.

Kondisi tersebut dapat terjadi karena apabila perusahaan-perusahaan sampel mendapatkan laba, maka mereka cenderung untuk menggunakannya untuk memperbaiki struktur permodalannya, misalnya dengan membayar hutang. Hal ini sesuai dengan penjelasan model dua bahwa apabila perusahaan sampel mendapatkan keuntungan, mereka cenderung 
untuk tidak melakukan kegiatan investasi, tetapi cenderung untuk memperbaiki struktur pendanaannya

\section{PENUTUP}

\section{Kesimpulan}

Dari hasil analisis model yang telah dibuat, dapat diambil kesimpulan bahwa, komponen laba rugi yang terdiri atas perubahan laba bruto, perubahan laba operasi dan perubahan laba bersih satu tahun sebelumnya, signifikan untuk dipergunakan sebagai prediktor komponen arus kas dari kegiatan operasi, dan secara individual masing-masing komponen tersebut menunjukkan pengaruh yang signifikan. Akan tetapi, Komponen laba-rugi yang terdiri atas perubahan laba bruto, perubahan laba operasi dan perubahan laba bersih satu tahun sebelumnya tidak dapat dipergunakan sebagai prediktor komponen arus kas dari kegiatan investasi, karena nilai $\mathrm{R}^{2}$ dan nilai $\mathrm{F}$ menunjukkan angka yang tidak signifikan, berarti kemampuan komponen laba-rugi tersebut secara keseluruhan tidak signifikan untuk menjadi prediktor komponen arus kas dari kegiatan investasi. Demikian juga pengaruh masing-masing komponen laba-rugi secara individual tidak signifikan, berarti ketiga komponen tersebut tidak memiliki kandungan informasi terhadap arus kas dari kegiatan investasi perusahaan sampel. Namun demikian, ketiga komponen laba-rugi yaitu perubahan laba bruto, perubahan laba operasi dan perubahan laba bersih satu tahun sebelumnya secara signifikan dapat menjadi prediktor arus kas dari kegiatan pendanaan. Hasil pengujian menunjukkan bahwa perusahaan sampel cenderung menggunakan laba yang diperoleh dari tahun sebelumnya untuk memperbaiki struktur pendanaan usahanya, dari pada untuk kegiatan investasi.

Berarti komponen laba-rugi tidak identik dengan komponen arus kas apabila digunakan sebagai dasar analisa untuk pengambilan keputusan bagi pihak yang berkepentingan dengan perusahaan. Dengan demikian, diterbitkannya laporan arus kas oleh perusahaan akan memberikan nilai tambah bagi pihak pemakai informasi laporan keuangan, baik internal maupun eksternal.

\section{Saran}

Data seri waktu (time series) tentang komponen laba-rugi dan komponen arus kas bermanfaat untuk proses pembuatan keputusan ekonomik, oleh karena itu penelitian tentang komponen laba-rugi dan komponen arus kas serta keterkaitan antara keduanya merupakan topik yang menarik untuk diteliti lebih lanjut.

Penelitian tentang kemampuan prediksi komponen laba terhadap komponen arus kas dapat dilakukan dengan menambah variabel ukuran (size) perusahaan sebagai variabel kontrol, sehingga dapat diketahui seberapa besar perbedaan kemampuan prediksi komponen laba pada perusahaan besar dan perusahaan kecil terhadap komponen arus kasnya.

\section{DAFTAR PUSTAKA}

Abdullah, 2019. Pengaruh Kinerja Keuangan Terhadap Harga Saham Perusahaan Kelompok Jakarta Islamic Index, AkMen JURNAL ILMIAH, 16 (4): 516-528.

Adnyani, R. D. 2015. Kemampuan Laba, Arus Kas Operasi Dalam Memprediksi Arus Kas Masa Depan. Denpasar: Universitas Udayana.

Fuji Sri Mar'ati. 2009. Pengaruh Laba Akuntansi dan Arus Kas Terhadap Abnormal Return Saham. Among Makarti, 2 (4). 
Givoy, D., dan Hayn, C., 2000, The Changing Time-Series Properties of Earnings, Cash Flows and Accruals: Has Financial Reporting Become More Conservative? Journal of Accounting \& Economics, 29 (2000): 287-320.

Gujarati, D. N., 1995, Basic Econometrics. Singapore: Mc Graw-Hill Inc.

Jordan Setiawan S. 2015. Pengaruh Laba Kotor, Laba Operasi, Laba Bersih Dalam Memprediksi Arus Kas Masa Mendatang. Universitas Jember.

Kuncoro, Mudrajad, 2001, Metode Kuantitatif, Teori dan Aplikasi Untuk Bisnis dan Ekonomi. Yogyakarta: Unit Penerbit dan Percetakan AMP YKPN,

Lorek, K.S., 1996, A Multivariate Time-Series Prediction Model For Cash-Flow Data, Journal The Accounting Review, (1): 81-102.

Maulidia, Risa, 2018. Kemampuan Informasi Laba dan Arus Kas Dalam Memprediksi Arus Kas Masa Depan. E-JRA FEB Universitas Islam Malang, 07 (09): 1-11.

Mufidah, E. 2017. Analisis Laba, Arus Kas Operasi Dan Nilai Buku Ekuitas Terhadap Harga Saham. Eksis: Jurnal Riset Ekonomi dan Bisnis, 12

Nany, M. 2013. Analisis Kemampuan Prediksi Arus Kas Operasi (Studi pada bursa efek Infonesia). Jurnal Dinamika Akuntansi, 5(1), 35-46

Prayoga, Irfan Bagus. 2012. Pengaruh Laba Bersih dan Komponen-komponen Akrual Terhadap Arus Kas Aktivitas Operasi di Masa Mendatang. Semarang: FEB UNDIP.

Subramanyam Wild, J. J. 2010. Analisis Laporan Keuangan. Jakarta: buku 1 Edisi ke 8. Salemba Empat.

Sugiri, S., 2003, Kemampuan Laba Rincian Untuk Memprediksi Arus Kas, Disertasi. Yogyakarta: Fakultas Ekonomi UGM.

Susilowati, Y. 2011. Reaksi signal rasio profitabilitas dan rasio solvabilitas terhadap return saham perusahaan. Dinamika Keuangan dan Perbankan, 3 (1).

Sutedja, Akdi. 2018. Pengaruh Laba Kotor, Laba Operasi, Laba Bersih Dalam Memprediksi Arus Kas Di Masa Mendatang Pada Perusahaan Yang Terdaftar di Bursa Efek Jakarta. Jakarta: FE Universitas Satya Negara Indonesia.

Yuwana, V. dan Jogi Cristiawan, Y. 2014. Analisa Kemampuan Laba dan Arus Kas Operasi dalam Memprediksi Arus Kas Operasi Masa Depan. Business Accounting Review, 2 (1). 